Cameroon : The Retrenched Workers of the Civil Service and Parastatals. Assessing the Needs for the Reforms

Bayie Kamanda

\author{
(2) OpenEdition \\ Journals \\ Electronic version \\ URL: http://journals.openedition.org/apad/453 \\ DOI: 10.4000/apad.453 \\ ISSN: 1950-6929 \\ Publisher \\ LIT Verlag \\ Printed version \\ Date of publication: 15 December 1999
}

Electronic reference

Bayie Kamanda, «Cameroon: The Retrenched Workers of the Civil Service and Parastatals. Assessing the Needs for the Reforms », Bulletin de l'APAD [Online], 18| 1999, Online since 19 September 2006, connection on 07 September 2020. URL : http://journals.openedition.org/apad/453 ; DOI : https:// doi.org/10.4000/apad.453

This text was automatically generated on 7 September 2020 .

Bulletin de I'APAD 


\title{
Cameroon : The Retrenched Workers of the Civil Service and Parastatals. Assessing the Needs for the Reforms
}

\author{
Bayie Kamanda
}

1 Efforts to overhaul and reform or the Cameroonian civil service and parastatals in terms of wage and employment begun by 1995 . As will be observed, we have integrated public enterprises in our analysis on an equal footing, for they function along the same logic as the civil service, with State subventions and under State control. This similarity explains moreover why public enterprises were required to sign Performance Contracts submitted by the State within its civil service reform policy which included therefore their rehabilitation.

2 According to official documentation in this matter (Commis de l'Etat January-March 1996), June 19, 1995 marks the official launching of the reforms of payroll containment in the Cameroonian public service, better known by its French acronym Programme de la réforme de la fonction publique camerounaise (PREPC), whose fundamental objectives were articulated around the two following elements :

- the mastery of the payroll by a mastery of the numbers of civil service workers ;

- the quest for better returns in the civil service, by improving its efficiency, and in consequence, that of the public administration.

3 Thus understood, the state agents of the civil service who were laid-off were considered as over-staffing, this being established following an evaluation of the needs of their respective ministries. Consequently, these over-staffed state agents were those who could not be inserted in the process of reform, or those selected on some disciplinary grounds. The reforms were programmed to end in 1997, depending on what was then termed the POE (Programme d'organisation des effectifs) of the ministries concerned.

4 Like in most developing countries, the need for a better administrative capacity of the public sector, both in the core civil service and in the public enterprises, was brought 
into relief within the reform. The main arguments were that the ability of the civil service to carry out its government functions were increasingly constrained. Furthermore, the size and cost of the civil service were becoming excessive. These deficiencies therefore became key issues and targets of structural adjustment programmes. As argued by the World Bank (1994), the growing concern with containing the size and improving the performance of the civil service signifies a reframing of the role and the dimension of the State, reflecting a fundamental shift in economic development policy (Vito \& Ludger 1996).

The civil service and employment reform resorts to various mechanisms including the removal of ghosts and posts ; enforcing retirement regulations ; freezing recruitment ; eliminating guaranteed rights; containing wages and retrenchment. Although in the case of Cameroon retrenchments included "voluntary" departures from the civil service, retrenchments generally refer to the dismissal of those who are considered redundant civil servants.

6 Many sources agree that the retrenchment option is most probably the most difficult one to implement and generally constitutes for a government the last resort in these matters. As Nunberg argues (1994), this reluctance is related to the nature of the State in many developing countries, as the central source of political patronage and social welfare through the provision of public posts to loyal followers and deserving clients. Hence, overt employment reduction basically conflicts with the very role of State. Moreover the fear of political regimes that retrenchment will incite destabilizing social upheavals and political opposition serves as a sufficient reason to stiffen the resistance to these measures. In the case of Cameroon, retrenchments happened during the political transition toward multipartism. The ruling party, the Cameroon Peoples Democratic Movement (CPDM), stood under the pressure of losing its leadership over the country. This tense political context must be taken into account for the assessment of the 1995 retrenchment policy : one might in particular ask why it took place at that time.

7 In Cameroon, retrenched workers constitutes nowadays a societal phenomenon, representing the former employees of the public service and State corporations who lost their jobs (including those by voluntary departures) in consequence of the application of the following six component of macro-economic policy: (1) the operation "Antilope" ; (2) the overhaul of the payroll ; (3) "Performance Contracts" ; (4) the rehabilitation of State enterprises and corporations; (5) the restructuring of the banking system ; (6) State disengagement and privatization.

8 The background of such reforms is constitute by development planning policies ${ }^{1}$, based in Cameroon on five-years programs, the last of them being the fifth plan (1981-1986). The reforms of the 1980s were thus pegged on three important objective regarding: (1) the relationship between employment and social welfare, (2) poverty alleviation, and (3) participation and good governance, and therefore democratization, as will be explained below. On this basis, the implementation of the 1995 reforms has to be assessed in the terms of appropriateness, poverty concerns, and regarding the government's capacity to follow its developmental objectives.

9 This chapter aims at analyzing the need for these reforms in Cameroon. For that purpose, we will review the current civil service and employment reforms, namely the national retrenchment policy, within the context of the employment and labor policy of the late 80 s, briefly sketched out above. This study in public policy includes the 
analysis of official government employment and labor policies, of their sectoral logics, and of their implementation by the State. Employment Policies in Cameroon are mainly implemented mainly through the following State agencies : the Ministries of Labour, of Public Service and Administrative Reforms, of Public Investments and Territorial Administration, and the Directorate of planning in the Ministry of the Economy and Finance (MINEFI).

The article derives essentially from data collected in these public institutions, in particular in the services responsible for employment-generating investments.

The need for reform

Our main concern here is whether the need for reform in Cameroon is in consonance with what took place in most Third World countries, summarized by Nunberg (1994) as resulting from the inability of Third World country governments to manage and finance their civil services, and from the fact that civil services themselves would have suffered from three diseases : too large, too expensive and insufficiently productive. We shall start by presenting each of these arguments.

Argument 1: An overstaffed Cameroonian public service

This argument would be based on the practice of compensation in recruitments into the Cameroonian public service provoking a loaded public service, without corresponding to any technical or economic logic.

Then the civil service was too large for two reasons; firstly due to the over-development of public agencies and organizations charged with too broad and blurred responsibilities; secondly, many agencies employ too many workers vis-à-vis their needs. The over-staffing itself necessarily results in poor motivation, in low - or extremely low - renumeration scales for upper and middle managerial positions, in comparison with the private and even the parastatal sectors.

14 It is also noteworthy that many civil servants were insufficiently productive in the sense that they did not fulfill the tasks assigned to them (ineffectiveness), or they carried out their assignments partially, with great delays, at high cost (inefficiency).

Argument 2 : An overpaid Cameroonian public service

15 This argument supports the view that responses to macro-economic policies 100 to inappropriate salary polices which in turn contributed to the decline of state performances as far as employment is concerned.

16 It appeared rather glaringly clear thus, that for a long time, state employment in Cameroon received a large pay packet. The civil service was too expensive because public sector wage bills constituted too high a percentage of total government revenues and accounted for too high a percentage of GDP. Furthermore, the CFA zone countries (including Cameroon) notwithstanding the specific constraints imposed by this particular monetary system, did not experience any hard fan of real wages as were observed in English-speaking countries, as a result of monetary and economic reforms.

17 It is evident that within the background of these arguments, reforms were deemed necessary. Hence the World Bank (1994) programs sought to tackle this "civil service syndrome" by focussing on four principal problems in the case of Cameroon : excessive government wage bills, surplus service employment, salary erosion, and wage compression.

The retrenchment policy 
Official documentation projected the layoff of 30,000 workers in all the sectors of employment in the public service and state enterprises as a consequence of the economic crises.

Partly funded by a subvention of 8 billion franc by the Caisse française de développement, and the Cameroonian public treasury, retrenched workers received 24 months of their basic salaries on departure, salary arrears of September and October 1993, arrears memorized in the computers of the salary department, subscriptions and contributions in the form of pension benefits ( $10 \%$ for the fonctionnaires, and $7 \%$ for those covered by the labor code). As an example, among the 105 persons retrenched from the Ministry of the Public Service and Administrative Reforms, the amounts of compensation varied between 1,016,511 and 6,039,560 francs CFA (Commis de l'Etat n05, Nov.-Dec. 1999).

As backup to the reforms, Social Dimension of Adjustment Projet, as a component of the reform (République du Cameroun 1990), proposed the implementation of measures aiming at improving the functioning of the labor market and at supporting the creation of new jobs, through the recycling and reinserting of an impressive number of workers, notably of the following groups :

1. employees of the private, public and state corporations who would loose their jobs during the transition phase of the implementation of the structural adjustment plan.

2. youths, holders of the first degree or drop-outs from school ;

3. the poorest and most vulnerable groups of the population, amongst which women without qualifications and young people with an insufficient resource levels to invest in self-employment.

The main actions destined to promote employment within the framework of the SDA project were supposed to be undertaken though the National Employment Fund (NEF) created for the funding of the following five activities :

a. the systematic collection and diffusion of data on the openings in training in employment opportunities.

b. the reinforcement of formal professional training.

c. support to in-service-training.

d. support to individual initiatives targeting self employment ; and,

e. a technical and financial assistance towards the creation of micro-enterprises.

In addition, the SDA project of the SAP was to fund several studies which would contribute to the formulation of a national employment sectoral policy as well as to reinforce the planing capacity of the Ministry of Labor and Social Insurance.

The SDA project was equally required to fund the following activities: the national survey on employment of the Ministry of labor and Social Insurance (which begun but was stopped due to lack of funds) ; the definition of criteria for the evaluation of public investment programs; and the following four preliminary studies.

- a profile of employees laid-off from state enterprises ;

- the study of the capacity of the central services in professional training ;

- an evaluation of the possibility of the creation of national corps of voluntary service in order to provide practical professional training to the young unemployed;

- an evaluation of the creation of jobs in the informal sector ; 
the National Employment Fund was charged with assisting retrenched workers in their conversion into productive activities. Three workshops were organized to this purpose with the following goals and objectives: the seeking of a paid job; reconversion into the function of an entrepreneur; technical backup. To this must be added the fact that the following ministries: Public Investments and Territorial Administration; Agriculture; Social and Women's Affairs; and National Education were each required to institute specific strategies for supporting the retrenched workers in their conversion and progressive reinsertion into economic and productive life.

The measures workers, was to be carried out in 1995 (MTM 11.12 92 : 3314), in the following manner :

- 39 state corporations were liquidated or in the process of liquidation ;

- 29 state enterprises were maintained within the State portfolio, and were earmarked for rehabilitation. Amongst these, 25 had signed "Performance Contracts" with the State as early as in September 1992. Other similar contracts were underway for signature.

- Studies were carried out on 16 public enterprises, to be presented to the inter-ministerial committee during the autumn of 1992 ; notably enterprises of the industrial, petroleum, maritime post and telecommunication sectors.

- 46 enterprises up to 1992, and despite the measures taken, had not yet been subjected to such studies and diagnostics.

- 15 enterprises were officially classified as to be privatized, amongst which three were actually privatized.

- In the financial sector, 5 commercial banks were liquidated, 4 financial institutions were under restructuring, amongst which the National Investment Cooperation (Société nationale d'investissement, SNI), while 9 of them had not yet been studied including 4 Insurance companies and 5 public institutions created after the creation of Mission for the rehabilitation of the state enterprises (MTM $1992: 3314$ ).

above document clearly lays a lot of emphasis on the financial implications of these reforms. However, as far as our topic is concerned, it highlights the impact of the reforms on the retrenchment of the 30,000 workers referred to above.

The employment policy of the 1980 s following three principles : the relationship between employment (or jobs) and social welfare, the easing or reduction of poverty, the issues of participation and good governance, and therefore of democracy, considered as crucial assets for development. In effect, up till 1987, government action on employment was targeted towards the reinforcement and the extension of employees' protection regarding the different risks they face, the organization of professional relationships within the enterprises aiming at a better understanding between social partners, the progressive reduction in inequalities between the different groups of workers, sectors and regions, and the harmonization of texts and structures at the national level.

Then, a fundamental reform in the pay roll was introduced by a Decree of 3 May 1976 which suppressed the notions and practices of SMIG and SMAG. Moreover, the government was periodically brought to review the salaries upwards. Salary increases were digressive, favoring workers at the bottom of the wages scale. Furthermore, a 
particular effort was accomplished in favor of workers in what was termed the "third salary zone", including the great majority of enterprises of the primary sector, with the highest demands for labor.

These measures improved on the working plights of workers found in the lower salary scales. In the third salary zone (representing thus the lowest salary brackets), and for the first three categories, the cumulative increases in salaries was of $40 \%$ or so in 1980 (Ahmadou 1980).

The legislative and statutory dispositions instituted in order to harmonize working conditions and wages within each industrial branch at the national level were undertaken following a vast movement of negotiation of national collective conventions which had begun in $1976^{2}$, carried out with representatives of the National Union of Cameroonian Workers (UNTC), and with one or several employers' syndicates, and concerning ail the employees and workers of each branch of activity in the country.

40 As a protection of the workers against aggressions and risks likely to undermine or reduce his purchasing power, family allowances, industrial accidents, and professional illnesses, old age pension and deaths were introduced into the Cameroonian system of social insurance.

41 It is important here to underline the participatory character of decision-making processes : all these legislative and statutory measures were undertaken by the public powers in consultation with concerned social partners and stake holders. The latter were always associated in the definition and implementation of social policies through representatives from employer's associations and worker's unions in the Conseil national du travail et de la Commission nationale paritaire des conventions collectives et des salaires (Ahmadou 1980).

Assessing the need for the 1995 reforms

We must now review the current civil service and employment reform - the retrenchment policy -, within the context of the national operational employment and labor policy of the late 1980s. We will analyze the three so-called diseases the civil service suffer, namely to be too large, too expensive and insufficiently productive.

An overstaffed Cameroonian public service

Up to 1987 the annual growth rate in the Cameroonian civil service was estimated at $10 \%$ for the functionaries, increase distributed as follows :

- For the contract workers, a steady increase in their numbers until 1987 with specific peak increases in 1983, and 1986, corresponding to specific dates in the recruitment of degree holders (1,500 of them in 1983 and 1,700 in 1986).

- The census of public service workers and state agents (1987) which, according to official documentation, permitted to identify 7,796 cases of irregularities (ghost workers) in civil service recruitments for functionnaires and for 1,501 cases of contract workers.

- The number of daily paid workers increased up to 1987 ; but given the irregularities identified, and the text on the reduction of the retirement age for personnel guided by the labor code (1993), the number of daily paid workers reduced till 1998. An idea of this evolution till 1994 can be observed from the following table (page 13).

The table indicates the regular progression in the different categories of civil servants up to 1987, with two breaks in 1988 and 1989. If we consider the period from 1984 (ten years before the implementation of the 1995 reforms), we observe that this first peak 
period corresponds to the integration of the findings of the 1987 state agents census (Opération "Antilope") of 1987. The second peak (1991) was dictated by the operation of overhauling the payroll data base. Thus, as from 1993, a regular drop in the numbers of state functionaries, contract officers and daily paid workers is apparent. This drop is due to 1980 reforms with as objectives, the mastery of the numbers of public service workers (see the decree 74/138 and its subsequent modifications, particularly article 171(1) and the decree 94/199 article 132, on the enforcement of retirement after 30 years of service).

Table 1 : Evolution in the numbers of civil servants (1984-1994)

\begin{tabular}{|c|c|c|c|c|c|c|c|c|}
\hline Year & A2 & A1 & B2 & B1 & C & D & Total & Growth \\
\hline 1984 & 3.156 & 4.657 & 1.538 & 10.416 & 16.542 & 12.574 & 48.883 & -4.980 \\
\hline 1985 & 3.578 & 5.168 & 1.698 & 11.455 & 17.282 & 13.019 & 52.200 & -3.317 \\
\hline 1986 & 3.790 & 5.565 & 1.768 & 12.042 & 18.036 & 13.242 & 54.449 & -2.249 \\
\hline 1987 & 4.534 & 6.649 & 2.103 & 13.626 & 19.944 & 13.857 & 60.713 & -6.264 \\
\hline 1988 & 4.721 & 7.109 & 2.157 & 13.471 & 16.300 & 9.159 & 52.917 & -7.796 \\
\hline 1989 & 4.783 & 7.277 & 2.236 & 18.880 & 16.507 & 9.014 & 53.697 & -780 \\
\hline 1990 & 7.163 & 9.779 & 3.134 & 19.616 & 22.900 & 11.426 & 74.018 & +20.321 \\
\hline 1991 & 7.368 & 9.218 & 3.005 & 19.156 & 22.621 & 9.926 & 71.294 & -2.724 \\
\hline 1992 & 7.665 & 9.533 & 3.006 & 19.455 & 23.311 & 9.979 & 72.949 & -1.655 \\
\hline 1993 & 8.657 & 9.500 & 2.747 & 18.481 & 22.510 & 9.392 & 71.269 & -1.680 \\
\hline 1994 & 10.506 & 11.382 & 3.071 & 23.624 & 24.435 & 9.594 & 79.692 & -8.423 \\
\hline
\end{tabular}

Source : Le Commis de L'Etat 5 (Nov-Dec 1999 : 27)

Secondly, some reductions had been undertaken in the parastatals in 1992. Thus, the textile sector with the Confection industrielle camerounaise (CICAM) practically disappeared whereas it has created 8,000 jobs during the late 1970s. (MTM 11.12.92: 3330). The National Marketing Board (ONCPB), or Office national de commercialisation des produits de base, maintained a labor force of only 2,800 persons until 1988/89 because of a $32 \%$ cut in its budget. The Société de développement de la cacaoculture (SODECAO) kept a labor force of some 30,000 persons until the 1988/89 fiscal year when the figures dropped to 3,000 during the $1989 / 90$ fiscal year.

Third, the government froze employment from 1990, and was concerned with two employment-reduction mechanisms before (1981-1990), namely the removal of ghost 
workers (including double payments) and that of enforced and early departures from the civil service.

Table 2 : Employment reduction by mechanism, some countries : UDEAC zone 1981-90

\begin{tabular}{|c|c|c|c|c|c|c|c|}
\hline \multirow[t]{2}{*}{ Country } & \multirow[t]{2}{*}{$\begin{array}{l}\text { Ghost } \\
\text { removal }\end{array}$} & \multirow[t]{2}{*}{$\begin{array}{l}\text { Enforced/ } \\
\text { early } \\
\text { retirement }\end{array}$} & \multirow[t]{2}{*}{$\begin{array}{l}\text { Voluntary } \\
\text { departures }\end{array}$} & \multicolumn{2}{|c|}{$\begin{array}{l}\text { Retrenchment } \\
\text { of staff }\end{array}$} & \multirow[t]{2}{*}{$\begin{array}{l}\text { Other } \\
\text { mecha } \\
\text { nisms }\end{array}$} & \multirow[t]{2}{*}{ Total } \\
\hline & & & & Regular & $\begin{array}{l}\text { Tempo } \\
\text { rary }\end{array}$ & & \\
\hline Cameroon & 5.830 & 5.000 & 0 & 0 & 0 & 0 & 10.830 \\
\hline $\begin{array}{l}\text { C.Afr. } \\
\text { Rep. }\end{array}$ & 2.950 & 0 & 1.200 & $350-400$ & 0 & 0 & $4.500-4.550$ \\
\hline Congo & 0 & 0 & 0 & 0 & 0 & 2.848 & 2.848 \\
\hline
\end{tabular}

Source : Lindauer \& Nunberg (1994 : 129)

47 We may agree with Nunberg (1994) that for cases for which data is available (like those of Cameroon), the reduction of civil service cadres through the elimination of ghost workers, appears to be an effective technique in emergency cost-containment programmes. In fact nobody doubts the illegality of keeping ghost workers and the illegal drain in the national salaries. Moreover, enforcing appropriate retirement rules for overage civil servants represents an attractive option for employment reduction. Certainly it usually targets a small group, and often one that is quite valuable, considering the dearth of trained professionals, but with notably little political opposition if the retirement benefits are paid and timely.

The concentration of the reforms on these two mechanisms (of ghost removal and early/enforced retirement), require to question the need for the retrenchment measures of 1995. A difficulty in defining overstaffing, stems from the heterogeneous character of the respective ministries involved in employment issues, and this from three angles: their specific nature, their size, and their objectives. In this respect, whereas there was a real need for an increase (or at least the maintenance) of the number of staff in some ministries, the situation was not the same for ail of them. The need for retrenchments was for instance expressed in the case of the teachers at both secondary and high school levels as well as for medical staff.

In addition, these reforms challenge the daily unemployment concerns of the State, a main preoccupation of the National Employment Food (FNE). It is from this point of view that General Manager of the National Employment Food complained about the non-payment of the employers' contribution of $1 \%$ of 300,000 francs CFA/month, instituted by decree of 27 April 1991 creating FNE, but without any text of application, which fact acted as the main limitation of his service in the fight against unemployment, and accordingly undermined its efforts in this matter.

The problem of unemployment is still harshly felt in Cameroon. The 1997 General Census on Housing and Population (GCPH) shows that, among the population of 
Cameroon of $13,090,000$, the total active population was of $5,108,000$ meanwhile the working population was of 4,852,600. Thus 255,400 Cameroonians were "active" but "unemployed". In the same order of ideas, and as confirmed by the National Household Consumption survey (ECAM), the data is the following :

\begin{tabular}{|l|l|l|}
\hline Active unemployed pop & & 391,403 \\
\hline \hline & Adult Men & 240,961 \\
\hline \hline & Women & 150,442 \\
\hline \hline & Boys & $19.2 \%$ \\
\hline \hline Unemployed in Yaoundé & Girls & $17.0 \%$ \\
\hline \hline Unemployed in Douala & & 98,150 \\
\hline \hline Percentage with university degree & & 111,062 \\
\hline \hline Percentage with GeE "A" levels & & $16.0 \%$ \\
\hline \hline Without GCE "A" Levels & & \\
\hline
\end{tabular}

51 Data for the Ministry of the Economy and Finance for May 1994 (for Yaoundé only) are as follows :

\begin{tabular}{|l|l|}
\hline Total pop. of Yaoundé & 857,000 \\
\hline \hline Active population & 610,000 \\
\hline \hline Population unemployed & 296,000 \\
\hline
\end{tabular}

(Sources : Cameroon Tribune n²954 19 Aug. 1999: 5)

52 These figures give us an idea of the situation of unemployment in the country and justify the drive against unemployment currently carried out by the government. In effect until 1998, according to the General manager of the National Employment Food, (Cameroon Tribune $\mathrm{n}^{\circ} 2954$ of Saturday, August 9, 1998) un employment reduction efforts were carried out around four main axes : (1) the acceptance and orientation of job seekers, (2) the collection and diffusion of information on the situation of the labor market, (3) the matching of labor supply with the demand for labor, and (4) support to self employment and micro-enterprises. 

new. Thus, in the analysis of the programmed expenditure for the 1999/2000 fiscal year, the global volume of expenditure for the current fiscal year were 1,297.6 billions francs CFA distributed as follows : 1,275 billions for the State budget and 22.4 billions for the annex budget of the Ministry of Post and Telecommunications (P\&T). Expenditure on personnel for the same period amounts to 296 billions francs CFA. This is an increase in absolute value of 17 billions francs CFA (+6.1\%) vis-à-vis the budgetary provisions of the 1998/999 fiscal year (Cameroon Tribune 17 june 1999). Within this programming, Cameroon is employing 340 more graduates coming from the institutions of higher learning (Cameroon Tribune 21 April 1999).

The impact of the CFA devaluation on salary revalorization in real terms.

According to this argument, African countries of the Franc CFA zone of which Cameroon is part, because of particular constraints imposed by the management of their monetary systems did not experience the precipitated fall in their real salaries as was the case with English-speaking countries, non-members of the same monetary zone.

59 This is not true for an economy heavily dependent on imports for basics like drugs, replacement parts for machines and industries, school equipment, as in the case of Cameroon. In effect, the real value of salaries is also function of the inflationary rate. One of the consequences of the devaluation of the CFA franc was indeed an appreciation in the price of Cameroonian exports; but this increase was much lower than the inflation of the prices of basic imports which in some cases has remained up till now as high as $80 \%$. The argument of the consequence of the devaluation of the 
franc CFA on the revalorization of salaries in real terms does not necessarily therefore apply.

Conclusion

Assessing the need for the 1995 retrenchment of workers in Cameroon requires reference to development planing and employment policy. From a historical perspective, development planning in Cameroon was undertaken within specified five-years plans, the last of them being the fifth plan (1981-1986). The structures for the elaboration of the plans existed at both central and provincial levels. The central level was made up of the President of the Republic charged with the formulation of the general policy issues for the economic, social, and cultural national development plans. He was assisted by the Economic and Social Council, the National Assembly, and an Administrative and Consular structure. Twelve Commissions were generally involved in conformity with the former plans. Meanwhile, the provincial structures comprised of divisional development committees as well as committees of rural action.

61 Like elsewhere in developing areas, the developmental role of the State evolved in Cameroon from the direct State involvement of the 1980s towards withdrawal in the 1990s. One can argue that the failure of State-led development is explainable by the crises of the late 80s; leading to the State withdrawal and disengagement of the early 90s.

In relation to our topic, the reasons underlying the changing composition of public expenditure in Cameroon that provoked reduction in employment must be questioned. According to the World Bank's logic, the choice of compressions of personnel in public enterprises was indispensable for purposes of efficiency and of motivation, for a better management of the public affairs, the production and distribution of public goods, utilities and services, the definition and application of economic policy and the management of public expenditure at optimum levels. The civil service reforms therefore had an extended objective : the creation of a public service whose dimension, qualifications, motivations, behavior and the sense of responsibility would allow it to assure a better service corresponding to the expected role of the State.

But some trends contradict this ideal model, for instance the tight fiscal pressures applied by the World Bank and other funding agencies. In this matter and during the late 80s, few countries carried out their development programs in an independent or isolated manner, without the guidance of the World Bank, which became the main funding agency in the promotion of employment and wage reforms (that is during the 1990s eighty World Bank loans to forty different nations, World Bank 1994).

We have already noticed that the 1995 retrenchment policy in Cameroon broke away from the former employment and labor policy of the late 80s, based on concerns for social welfare, poverty alleviation, participation and good governance. One of the consequences of the retrenchment policy has been an increasing poverty nationwide, phenomenon compounded by the multiple negative consequences of the growing military spending and debt. Moreover, limited increases of public funding cannot do a lot to overturn pressure emanating from the labor market. In particular, the competition between funding agencies and donors, pushing experts' wages upward entailed a significant negative externality, because highly qualified labor was attracted out of the Cameroonian public administration. This in turn weakens the government's implementation capacity to reach national development objectives, capacity on which the community of funding agencies relies. All these mechanisms must be taken into 
account if one wish to truly assess the rationale of the retrenchment policy in Cameroon.

\section{BIBLIOGRAPHY}

Alert, L. \& March E. 1998. "Budget 1998/1999 : Presidential prescriptions, short on targets. Bill in preparation". Agenda for prosperity? 1 (3). Washington : The EITD Research legislative and Economic Advisory Service Programme.

Heidhues, F., Kamjou, F., Chataigner, J., Griffon, M., Fadani, A., Madi A., \& Temple L. 1994. Agricultural Price Policy and Export and Food Crop Production in Cameroon : A Farming Systems Analysis of Pricing Policies. Systems-oriented Research in Agriculture and Rural Development.

International Labor Organization. 1972. Employment, income and equity : A strategy for increasing productivity in Kenya. Geneva : ILO.

Lindauer, L.D. \& Nunberg B. 1994. Rehabilitating Government : Pay and Employment Reform in Africa. Washington DC : World Bank.

Padraig, F. 1995. "Putting the equality dimension into the mainstream". In : The Courrier 154 (Nov-Dec 1995), Bruxelles : ACP-EU.

Pouillaude, A. 1999. La "bonne" gouvernance, dernier-né des modèles de développement. Aperçu de la Mauritanie. Document de travail, Bordeaux : Centre d'économie du développement, Université Montesquieu-Bordeaux IV.

Présidence de la République 1992. Cameroun, 1982-1992. Des faits et des chiffres : le bilan de la décennie Biya. Yaounde : Présidence de la République, Cabinet civil.

République du Cameroun 1990. Projet "Dimensions sociales de l'ajustement structurel". Présentation à la conférence des bailleurs de fonds, Paris (Feb. 1990).

Schiavo-Campo, S. 1996. "Réformer la fonction publique". Finance et Développement : La réforme de l'État, Washington : World Bank (Sept 1996).

Tanzi V. \& Scuknecht L. 1996. "La réforme de l'Etat dans les pays industrialisés". ln : Finance et développement : la réforme de l'État, Washington De : World Bank (Sept 1996).

The Courrier 1994. "Fighting poverty". Brussels : General Secretariat ACP-EU (Feb. 1994).

The Courrier 1998. "Démocratie et bonne gestion de l'Etat". Brusells : General Secretariat ACP-EU (n¹71, Sept-Oct 1998).

\section{NOTES}

1.Development planning is understood as a co-ordinated set of measures and actions aiming at organizing the most efficient resources allocation in time and place. The term of policy involves questions about delegation (and thus accountability) and legitimacy regarding those in charge of the definition and implementation of policy measures. 
2.Thirteen collective conventions were already adopted before 1980 .

\section{AUTHOR}

\section{BAYIE KAMANDA}

Chargé de Recherche, Ministry of Scientific and Technical Research, BP 13179. Yaoundé, Cameroon - cogestion.iucn@camnet.cm 